\title{
The Development of Research on Telecounseling at Indonesia: A Literature Review
}

\author{
Cahyo Setiadi Ramadhan ${ }^{1 *}$, Fahmi Irfanudin ${ }^{1}$ \\ ${ }^{1}$ Department of Islamic Communication and Broadcasting, Faculty of Islamic Studies, Universitas Muhammadiyah \\ Yogyakarta,Indonesia \\ ${ }^{*}$ Corresponding author. Email: cahyosetiadil@umy.ac.id
}

\begin{abstract}
Technological developments brings changes counseling with its use as a long distance counseling medium. This research about this topic emerged in Indonesia. There are several research studied about researches on the topic. However, they studied the telecounseling's scientific literature in English and give no picture about the topic development in the scientific world of Indonesia. For that reason, the researcher in this study will examined the scientific literature on the topic in Indonesian to overview the development of research on telecounseling. Researcher examined Indonesian-language scientific sources indexed in Sinta under the counseling subject. The process found 41 Indonesia accredited journal on counseling. In the journals we discovered 10 articles and then reviewed them. It is found that the research on telecounseling in Indonesia developed to the level of describing detailed media or method used in telecounseling. However, the research about it's effectiveness undeveloped..
\end{abstract}

Keywords: Counseling, Research Development, Telecounseling, Telepsychology.

\section{INTRODUCTION}

Technological developments bring changes to society. In the field of counseling, these changes have an impact on the emergence of conditions that need to be handled by counseling related to the development of these technologies. On the other hand, technological developments also affect its use as a counseling medium $[1,2]$.

The development of the media to the stage of enabling distance counseling is known as telecounseling [3]. Telecounseling is a word referring to counseling using telephone, video conferencing, or internet media. In different scientific fields, the terms used are also different [4]. The American Psychological Association uses the term telepsychology to refer to psychological services that utilize all available technological advance [5]. In field of psychiatry, telemental health term used [6]. However, the essence of topic can be said to be the same [7], counseling or consultation between two sides or individual.

This development of using media to conduct telecounseling also occurred in Indonesia [8]. Telecounseling shows promising results [4, 8]. On the other hand, transforming face-to-face services in counseling or psychology into semi or non-face-to-face telecounseling does have many challenges [8]. The study of Mansyur, Badrujaman, Imawati, and Fadhillah also shows that although telecounseling has been carried out since 2008, various steps are needed to carry it out properly [9]. For that reason, it needs to be developed. Especially in the midst of the Covid-19 pandemic, telecounseling is increasingly needed [10]. Various health professional organizations or professional in the counseling sector recommend using remote services for consultation or counseling activities during the pandemic of Covid-19 [11, 12].

Literature review on telecounseling has been carried out using English-language literature sources [3, 9]. A literature review was also conducted on other similar forms of longdistance services, namely telemental health and telepsychology with English-language sources as well [6,7].

In this study, the authors examined the Indonesian language literature. The results of the study are expected to provide an overview of the development of research on telecounseling in Indonesia. The understanding of research development on telecounseling in Indonesia will give a view or picture about the development of telecounseling itself in Indonesia.

\section{METHOD}

The search was carried out by finding scientific journals on counseling that were nationally accredited at Sinta site. Manual searching of scientific articles were carried out on each page of accredited journals on the Shinta website to find scientific articles related to telecounseling. Articles related to telecounseling found are read carefully and reviewed. This kind of method was also used by several other previous studies on telecounseling Sari, Ramdhani, and Subandi searched for articles in scientific journals in the last 20 (twenty) years which were searched through search engines Google Scholar and Google, as well as the Pubmed journal database [7]. Another study by Mansyur, Badrujaman, Imawati, and Fadhillah looked for telecounseling topics from 
scientific journal databases namely Emerald, Taylor \& Francis, Springer, SagePub [9].

Here, researcher use Sinta website as the source of scientific articles to be studied. Sinta (Science and Technology Index) is delivering access to citations and expertise in Indonesia based on information systems and accessed through the website. This website was formed in 2016 by the Director General of Research and Development Strengthening of the Ministry of Research, Technology, and Higher Education. Sinta indexed only nationally accredited journals. Therefore, Sinta can be used to search reliable or good quality scientific resource [13].

\section{RESULT AND DISCUSSION}

The search for journals on counseling in Sinta found 41 nationally accredited journals on counseling. The results of the inspection of these journals resulted in the findings of 10 scientific articles related to telecounseling.

Four studies discuss online counseling in general $[14,15$, 16 , 17] including its form, media, and its results of success. The contents of the four articles can be summarized as follows:

a. To conduct online counseling, it is necessary to have counseling skills and mastery of information and communication technology $[15,16,17]$. In addition, ethical and humanitarian awareness is needed [14]. The online counseling process consists of three stages, namely the preparation of media hardware and software, the counseling process, and the post-process [16]. There are several online counseling media, namely websites, telephone, email, Instant Messaging, Social Networks, video conference $[15,16]$. Kirana adds media applications such as Riliv and Facebook which also site based [17].

b. Ardi, Yendi, and Ifdil divide the forms of counseling into individual counseling via email, individual counseling via instant messages, group counseling by instant messaging, couples counseling by instant messaging, individual counseling by video conference, couples counseling by video conference, and group counseling by video conference [15]. Meanwhile, Kirana describes several forms of cyber counseling based on the media and implementation platform. The classifications are e-mail-based Cyber Counseling, Android-based Chat-Asynchronous Cyber Counseling, Text-Based Cyber Counseling Using Riliv Android Application, and Facebook-based Cyber Counseling [17].

c. According to Ifdil and Ardi online counseling can be effective, especially if it is done by video conferencing on a fast internet connection [16]. Ardi, Yendi, and Ifdil thought that online counseling can be more acceptable to individuals who have difficulty meeting face-to-face, barriers to direct counseling, or are lazy to speak [15].
Kirana stated that this form of online counseling is suitable for generation Y or millennials who are familiar with various forms of information media [17]. People in general are increasingly familiar with technology so it is suitable for undergoing online counseling. The difficulty in conducting online counseling is the counselee's feeling about the availability of a counselor within 24 hours. In fact, counselors are not always available [14].

Three studies found studied the use of certain media in online counseling and the performance of it's online counseling. The first is a study on cyber counseling with the help of Facebook [18]. The second concerns the use of internet sites for cyber counseling with a Reality approach [19]. According to the study, the cyber counseling that they do can increase self-disclosure in vocational students. The third is Rational Emotive Behavioral Therapy (REBT) using cyber counseling with chat media and video calls on WhatsApp [20]. According to them, the system they use can reduce anxiety in dealing with Covid-19. The last two studies which stated that the counseling results were promising from cyber-counseling did not use adequate trial methods such as quasi-experiments.

One study showed the need for online counseling using self-help methods [21]. Based on their research, it is known that teenagers in Tangerang have high enthusiasm for online counseling with self-help methods. This shows the urgency of online counseling. The forms that teenagers prefer based on the results of their research are interactive online forms with very specific feedback support, containing instructions, and elaboration/explanation of feedback, and presented with media images/graphics, text, and video. According to them, the self-help theme that can be developed involves personalsocial aspects, learning aspects, and career aspects. They suggest that counselors also improve their skills in using information and communication technology facilities so that they can run technology-based counseling services.

Two studies studied distance counseling media, namely television program with it's sakinah family lectures [22] and self-help books [23]. Both studies stated that the media they studied were adequate to be a means of counseling. However, they did not explain that the counseling media they were studying was a long-distance counseling medium (telecounseling). In other words, the two studies did not use the term telecounseling.

While searching articles related to telecounseling we also found several articles on counseling media applied to face-toface counseling in classrooms. However, these media can be applied face-to-face:

a. Video to reduce bullying behavior compiled by Rahman, Aryani, and Sinring can be watched and learned independently by students [24].

b. The video teaching how to deal with emotions compiled by Fitriyani and Rosalia can also be watched and learned independently [25]. 
c. The video developed by Choirunnisa, Wirasti, snf Hidayat to drive students in mastering soft skills can be used independently by students [26].

The videos are open and can be the media for long distance counseling (telecounseling) including online counseling. Nowadays, peoples able to share video online use various platforms online.

In the process of searching for scientific articles, it was also found articles discussing online counseling that were published in nationally accredited journals but did not appear on the Sinta website. For example, the research of Duniawati, Muksin, and Lukman about Ibunda.id. There are also scientific articles that discuss online counseling and published in accredited journals but in other fields of science other than counseling such as da'wah [1], social education [9], or information technology [28].

\section{CONCLUSSION}

There are terms to point out long distance counseling that are related but quite different. The terms that are widely studied in Indonesia are cybercounseling and online counseling. Telecounseling studies exist but do not use this terminology. Studies on telecounseling in Indonesia already developed to level of discussion about telecounseling methods in detail.There have been studies that have tried to show the performance of the telecounseling method but have not used an adequate trial method.

\section{ACKNOWLEDGMENTS}

This research was conducted using the research grant from the Lembaga Penelitian, Publikasi, dan Pengabdian Masyarakat (LP3M) Universitas Muhammadiyah Yogyakarta. Researchers are grateful for the support. However, this does not affect the independency of the researcher in conducting this research.

\section{REFERENCES}

[1] M. Nursalim, Peran Konselor Dalam Mengantisipasi Krisis Moral Anak Dan Remaja Melalui Pemanfaatan Media "Baru". Jurnal Bikotetik 1(2) (2017) 37 - 72.

[2] N.C.H. Wibowo, Bimbingan Konseling Online, Jurnal Ilmu Dakwah 36(2) 271-287. DOI:http://dx.DOI.org/10.21580/jid.36i.2.1773

[3] J.Z Bowman \& G.J. Neimeyer, Telecounseling, Journal of Clinical Activities, Assignments \& Handouts in Psychotherapy $\begin{array}{llll}\text { Practice 2(1) (2002) 77-87. DOI: } & \end{array}$ http://dx.DOI.org/10.1300/J182v02n01_10.

[4] D.S. Dorstyn, A. Saniotis, \& F. Sobhanian, A Systematic Review of Telecounselling And Its Effectiveness In Managing Depression Amongst Minority Ethnic Communities. Journal of Telemedicine and Telecare, 19(6) (2013) 338-346. DOI: https://DOI.org/10.1177/1357633X13501767

[5] Joint Task Force for the Development of Telepsychology Guidelines for Psychologists, Guidelines for the Practice of
Telepsychology, The American Psychologist 68(9) (2013) 791-800. DOI: 10.1037/a0035001.

[6] D.M. Hilty, D.C. Ferrer, M.B Parish, B. Johnston, E.J. Callahan, P.M. Yellowlees, The Effectiveness of Telemental Health: A 2013 Review, Telemed J E Health 19(6) 2013 444454. DOI: 10.1089/tmj.2013.0075.

[7] O.K. Sari, N. Ramdhani, \& Subandi, Kesehatan Mental di Era Digital: Peluang Pengembangan Layanan Profesional Psikolog, (2020) [Online]. Available: https://DOI.org/10.22435/mpk.v30i4.3311 [Accessed: Nov. 15, 2021].

[8] E.W. Saptandari, Covid-19 and Mental Health: The Growing Need of Telecounseling in Indonesia, Buletin Psikologi, 28(2) (2020) 99-112. DOI: 10.22146/buletinpsikologi.60720

[9] A.I. Mansyur, A. Badrujaman, R. Imawati, \& D.N. Fadhillah, Konseling Online Sebagai Upaya Menangani Masalah Perundungan di Kalangan Anak Muda, Jurnal Pendidikan Ilmu Sosial 29 (2) (2019) 150-154.

[10] T.M.H. Li., \& C.S.Y. Leung, Exploring student mental health and intention to use online counseling in Hong Kong during the COVID-19 pandemic. Psychiatry and Clinical Neuroscience, 74(10) (2020) 564-565. DOI: 10.1111/pcn.13117.

[11] Himpunan Psikologi Indonesia (Himpsi), Panduan Layanan Psikologi Dalam Masa Tanggap Darurat COVID19 Bagi Psikolog, Sarjana Psikologi, Asisten Psikolog dan Praktisi Psikologi, 2020. [Online]. Available: https://himpsi.or.id/blog/pengumuman2/post/panduanlayananpsikologidalam-masa-tanggap-daruratcovid19-edisi-1-101 [Accessed: Nov. 15, 2021]

[12] World Health Organization (WHO) \& United Nations Children's Fund (UNICEF), Pelayanan kesehatan berbasis komunitas, termasuk penjangkauan dan kampanye, dalam konteks pandemi COVID-19, WHO \& UNICEF, 2020.

[13] About, Sinta (Science and Technology Index) [Online]. Available: https://sinta.kemdikbud.go.id/about [Accessed: Nov. 15, 2021]

[14] Z. Ardi, Z., M.R.M. Putra, \& I. Ifdil, Ethics And Legal Issues In Online Counseling Services: Counseling Principles Analysis, Jurnal Psikologi Pendidikan \& Konseling 3(2) (2017) 15-22.

[15] Z. Ardi, F.M.Yendi, \& I. Ifdil, Konseling Online: Sebuah Pendekatan Teknologi Dalam Pelayanan Konseling. Jurnal Konseling dan Pendidikan, 1(1) I. (2013) 1-5.

[16] I. Ifdil \& Z. Ardi, Konseling Online Sebagai Salah Satu Bentuk Pelayanan E-konseling. Jurnal Konseling dan Pendidikan 1(1) (2013) 15-21.

[17] D.L. Kirana, Cyber Counseling Sebagai Salah Satu Model Perkembangan Konseling Bagi Generasi Milenial, al-Tazkiah 8(1) (2019) 51-63

[18] H. Prasetiawan, Cyber counseling Assisted With Facebook to Reduce Online Game Addiction, GUIDENA: Journal of Guidance and Counseling 6(1) (2016) 28-36.

[19] A. F. Prabawa, M. Ramli, \& L. Fauzan, Pengembangan Website Cybercounseling Realita untuk Meningkatkan Keterbukaan Diri Siswa Sekolah Menengah Kejuruan, Jurnal Kajian Bimbingan dan Konseling 3(2) (2018) 59-68. 
[20] D.V.K. Fakhriyani, I. Sa'idah, \& M.Z.H. Annajih, Pendekatan REBT Melalui Cyber Counseling untuk Mengatasi Kecemasan di Masa Pandemi COVID-19, Counsellia: Jurnal Bimbingan dan Konseling, 11(1) (2021) 56-70. DOI: 10.25273/counsellia.v11i1846

[21] F. Amriiani, E. Wahyuni, \& G. Komalasari, Gambaran Kebutuhan Online Self-Help Pada Siswa di SMA Negeri Kecamatan Tanggerang Kota Tanggerang, Insight: Jurnal Bimbingan dan Konseling 2(1) (2013) 44-51.

[22] Y. Romadhoni \& F.N. Laila, Bimbingan dan Konseling Islam Dalam Menangani Masalah Keluarga Melalui Acara Bengkel Keluarga TV9 Surabaya, Jurnal Bimbingan dan Konseling Islam 3(2) (2013) 125-139.

[23] D. Syamila \& Fitriyani, H. (2018). Pengembangan Self-Help Book untuk Membantu Peserta Didik Mengatasi Konflik dengan Orang Tua dalam Perspektif Konseling Realitas. Insight: Jurnal Bimbingan Konseling, 7(2): 133-139.

[24] A. Rahman, F. Aryani, \& A. Sinring, Pengembangan Media Video Bimbingan Konseling untuk Mengurangi Perilaku Bullying. Jurnal Psikologi Pendidikan \& Konseling: Jurnal Kajian Psikologi Pendidikan dan Bimbingan Konseling 4(2) (2018) 129-136.

[25] H. Fitriyani \& L. Rosalia, Pengembangan Media Video Tutorial untuk Mengenalkan Treatment Mengelola Emosi Marah Pada Peserta Didik Kelas X di SMK Cipta Karya Jakarta, Insight: Jurnal Bimbingan Konseling 7(2) (2018) 147153.

[26] S.C. Choirunnisa, M.K. Wirasti, \& D.R. Hidayat, Strategi Pengembangan Soft Skill Siswa SMK Melalui Media Video, Teraputik: Jurnal Bimbingan dan Konseling 3(3) (2020) 99106. DOI: 10.26539/teraputik.33276.

[27] D.S. Duniawati, U. Muksin, \& D. Lukman, Model Konseling Online Ibunda.Id, Irsyad: Jurnal Bimbingan, Penyuluhan, Konseling, dan Psikoterapi Islam 8(1) (2020) 1-18. DOI: 10.15575/IRSYAD.V8I1.1620

[28] N.C.H. Wibowo, F.I. Milenia, \& F.H.Azmi, Rancang Bangun Bimbingan Konseling Online, Walisongo Journal of Information Technology 1(1) (2019) 13-24. 